\title{
Research on Distribution Mode of Agricultural Products Cold Chain Logistics
}

\author{
Li Huaiyong \\ office of teaching affairs \\ Shenyang Aerospace University \\ Shenyang, China
}

\begin{abstract}
In recent years, with the adjustment of agricultural structure and improvement of resident consumption level, quantity and circulation of fresh agricultural products have been increased year by year, which results in higher demand for safety and quality of fresh agricultural products by the whole society. Therefore, it will have great significance for promoting constant income increase and guaranteeing consumption security of farmers by accelerating agricultural products cold chain logistics. Cold chain logistics is an important means to ensure food security and improve people's life quality. Developing cold chain logistics delivery mode suitable for our national condition has significant importance for developing rural economy; while the choice of logistics delivery mode is the core issue of cold chain logistics development in our country. It has certain realistic significance to promote socialization distribution, and it will have strategic significance for the development of cold chain logistics to choose an effective transportation delivery mode.
\end{abstract}

Keywords-agricultural products cold chain logistics; delivery; mode; revolution

\section{INTRODUCTION}

Food security has received more and more attention with the development of national economy and improvement of people's life quality. People have had increasingly higher demand for food freshness with the improvement of life quality, and thus fresh seasonal food has become kind of people's pursuit. Our country is a vast agricultural country where fruit and vegetable industry has become a mainstay industry which is just inferior to grain production with the overall production turnover ranking the second and third place in overall rural production output. However, the rotten degree of procured fruits and vegetables is serious with high logistics cost due to the weak fruit and vegetable industrial base, low organizational degree of farmers, backward fruit and vegetable procurement and circulation facilities and low quality rate of fruits and vegetables. According to evaluation by relevant department, loss caused by rotten fruits and vegetables is nearly 5 million kilos, which values 100 million yuan. This not only brings enormous economic losses for our country, but it also causes fatal losses for growers.

\section{COMPARATIVE ANALYSIS ON THE DEVELOPMENT OF AGRICULTURAL PRODUCTS COLD CHAIN LOGISTICS HOME AND ABROAD}

In America, Japan, Germany and other developed countries, refrigerated trucks or refrigerated containers during the transportation are all equipped with advanced information technology such as electronic data exchange system and so on by employing inter-modal like railway, roadway and waterway covering process including production, processing, storage, transportation and product sales for fresh and refrigerated chain. According to international standard, the food logistics cost can't exceed $50 \%$ of the total food cost. However, food logistics cost in China has exceeded $70 \%$ of total food cost due to the low efficiency and enormous losses during transportation.

Domestic research on cold chain logistics mainly focuses on macroscopic surface, while overseas research on cold chain logistics mainly concentrates on technological information. Therefore, domestic research on cold chain logistics should be further strengthened with more research on cold chain itself and cold chain logistics transportation and delivery.

\section{DELIVERY MODE AND ITS CHOICE OF AGRICULTURAL PRODUCTS COLD CHAIN LOGISTICS}

\section{A. Delivery mode of agricultural products cold chain logistics}

The delivery modes for agricultural products cold chain logistics can be divided into the following varieties according to cold chain logistics transportation conditions that transported agricultural products' need as well as features of various cold chain logistics delivery mode.

1) Third-party logistics enterprise alliance delivery mode

The enterprise alliance mode means that enterprise is allied with third-party cold chain logistics enterprise to complete enterprise's agricultural products cold chain logistics activity in the form of agreement, during which the infrastructure of cold chain logistics activity may be offered by third-party logistics service or offered by the two parties together. The main task of third-party logistics enterprise is to complete systematic planning of enterprise's cold chain logistics and enterprise's basic cold chain logistics activity. The enterprise keeps close contact with third-party logistics enterprise by information system 
so as to reach the purpose of management and control on the whole cold chain logistics process.

The third-party cold chain logistics enterprises are allied together to output specific improved logistics management and operation system by offering functional service during transportation section of cold chain. By adopting common delivery mode, it can complete delivery function for multiple enterprises at one time so as to effectively reduce delivery cost and raise delivery rate.

\section{2) Enterprise self-distribution}

The enterprise self-distribution means that growers send agricultural products that customers ordered to the destinations by themselves, which can be divided into two kinds, one is delivery by growers themselves and another is delivery by enterprise.

\section{a) Small-scale delivery by farmers}

This is the most commonly seen delivery means in rural cold chain logistics. Farmers send goods which need heat preservation to destinations by some simple methods for temperature treatment. This distribution means is only applicable to small-scale distribution with small demand quantity. If demand quantity is large, then this means is not applicable.

\section{b) Enterprise delivery}

Self-support cold chain logistics modes can be divided into first-party logistics oriented by manufacturing enterprise and second-party logistics oriented by retail enterprise, which means that enterprise completes cold chain logistics with their possessed facilities and tools by investing and procuring cold chain facilities and equipment. The first-party logistics means that seller manufacturers or suppliers organize logistics, and the core of these enterprises are production and supplying commodities.

c) Features of enterprise self-support delivery

Advantages: it has strong self-control capability for delivery of agricultural production. The operation efficiency of cold chain logistics can be improved by rational planning with reduction of circulation fees and cost so as to establish sound corporate image and master distributing channels of agricultural products independently, which is beneficial to industrial competition. Enterprise delivery can guarantee transported products' quality for a long time due to special transporting vehicles so as to complete long-distance transportation and delivery, so it can used for delivery if order is of great quantity. By self-support cold chain, enterprises can obtain maximum decision-making power and maximum freedom. Cold chain logistics delivery serves for enterprise's business strategy which can meet timely delivery of goods on the cold chain with various kinds, various groups and low quantity so as to improve enterprise's efficiency and service level.

Disadvantage: Investment with relatively large scale should be supported by strong capital strength and scale as well as technological strength. With the low professional level, there won't be interruption during actual delivery. The self-support cold chain mode can meet the special demand of logistics for self products with low professional level. The employment degree of cold chain is low with serious resources waste. Enterprise delivery has high cost which needs their own special transportation vehicles, such as agricultural products needing cold chain or heat preservation. Such kind of special transportation vehicles usually have high cost, needing sincere maintenance. Professional technicians are needed to conduct maintenance on vehicles so that the cost of delivery mode will be raised.

TABLE I. COMPARISON ON ENTERPRISE DELIVERY AND FARMERS' SMALL-SCALE DELIVERY

\begin{tabular}{|c|c|c|}
\hline & $\begin{array}{l}\text { Enterprise } \\
\text { delivery }\end{array}$ & $\begin{array}{c}\text { Farmers' small-scale } \\
\text { delivery }\end{array}$ \\
\hline $\begin{array}{c}\text { Deliver } \\
\text { y cost }\end{array}$ & $\begin{array}{l}\text { High cost of } \\
\text { delivery, human } \\
\text { power and } \\
\text { materials } \\
\text { investment }\end{array}$ & $\begin{array}{l}\text { Low cost of delivery, } \\
\text { human power and } \\
\text { materials investment }\end{array}$ \\
\hline $\begin{array}{l}\text { Deliver } \\
\text { y range }\end{array}$ & $\begin{array}{l}\text { Wide range of } \\
\text { delivery with } \\
\text { long-distance } \\
\text { delivery }\end{array}$ & $\begin{array}{l}\text { Small delivery range } \\
\text { which is applied to } \\
\text { surrounding areas of } \\
\text { origin place }\end{array}$ \\
\hline $\begin{array}{l}\text { Deliver } \\
\text { y } \\
\text { flexibil } \\
\text { ity }\end{array}$ & $\begin{array}{l}\text { Low flexibility } \\
\text { and massive } \\
\text { delivery quantity }\end{array}$ & $\begin{array}{l}\text { High flexibility and } \\
\text { small delivery quantity }\end{array}$ \\
\hline $\begin{array}{l}\text { Warran } \\
\text { ty time }\end{array}$ & long & short \\
\hline $\begin{array}{l}\text { Profess } \\
\text { ional } \\
\text { degree }\end{array}$ & Relatively long & low \\
\hline
\end{tabular}

Applicable conditions: by analyzing content in table 3.1 above, we can see that self-support cold chain logistics delivery mode is mainly oriented by large production or retail enterprises. Therefore, the features above have determined that this mode of high level is not applicable to enterprises with common scale. However, undeniably, professional third-party cold chain logistics delivery system has not been mature in our country since it is only used as wide delivery mode in our country temporarily.

3) Cold chain logistics delivery mode based on thirdparty logistics enterprises

Cold chain logistics operated by third-party is professional application in cold chain logistics, which provides professional logistics service mode independent from manufacturers and retailers and wholesalers. Cold chain logistics enterprises operated by third-party can provide services like refrigerated transportation, refrigerated storage and refrigerated processing and so on, and it can also provide effective and complete cold chain solutions for cold chain logistics's need so as to realize full-course monitoring of cold chain logistics with capability of cold chain supply chain. Its features can be concluded as follows.

Strengths: similar to traditional logistics outsourcing, development of professional third-party cold chain logistics enterprise is the necessity of cold chain logistics industry. Compared to self-support logistics, it has high professional degree and high efficiency with very obvious advantage of cost saving. This cold chain logistics delivery mode can't occupy lots of fixed asset, which coordinates production and operation more freely so as to strengthen enterprise's management flexibility, which can improve core competitiveness by centralizing strength. 
Weaknesses: enterprises can't control and master logistics delivery function directly without guaranteeing the timeliness of delivery and excellent quality of customer services with less profits by sharing interest with thirdparty logistics. In addition, enterprise has to assume risks of choosing logistics companies with low efficiency.

Applicable conditions: it is applicable to enterprises with small sizes, weak economic strength or newly established ones. Enterprises can outsource logistics business if their logistics asset is not strong or with less staff in logistics delivery department.

\section{4) Alliance Delivery mode for supply chain logistics}

The alliance mode of supply chain logistics means to make a logistics cooperation alliance with one or multiple partners on the supply chain focusing on enterprises by taking each node on the supply chain as a whole for the same goal. By particular system, supply chain management system can be formed by computer network and information technology and taking regional materials resources as selective objects combining various advanced logistics management and technology so as to combine node enterprises supply chain organically, and thus sharing resources such as personnel, process and technology can be better used to realize collaborative operation so as to provide logistics products or services that market needs of high quality and low cost fast and effectively.

From micro angle, it can raise the operation rate of cold chain logistics by realizing supply chain alliance of cold chain logistics so as to reduce operation cost and save massive funds, equipment, land and human power, promote enterprise's growth and expansion, enlarge market range, eliminate closed sales network and build environment for common existence and common sharing. From the perspective of whole society, it can reduce quantity of overall vehicles and improve traffic conditions by realizing cold chain logistics alliance so as to raise the vehicles' loading rate of cold chain logistics and save human resources of cold chain logistics as well as promote cold chain logistics environment, which can further improve the overall quality of social life. Besides, it can promote the timeliness of production plans and accuracy of demand so as to formulate products' delivery plans in advance and reduce delivery cost.
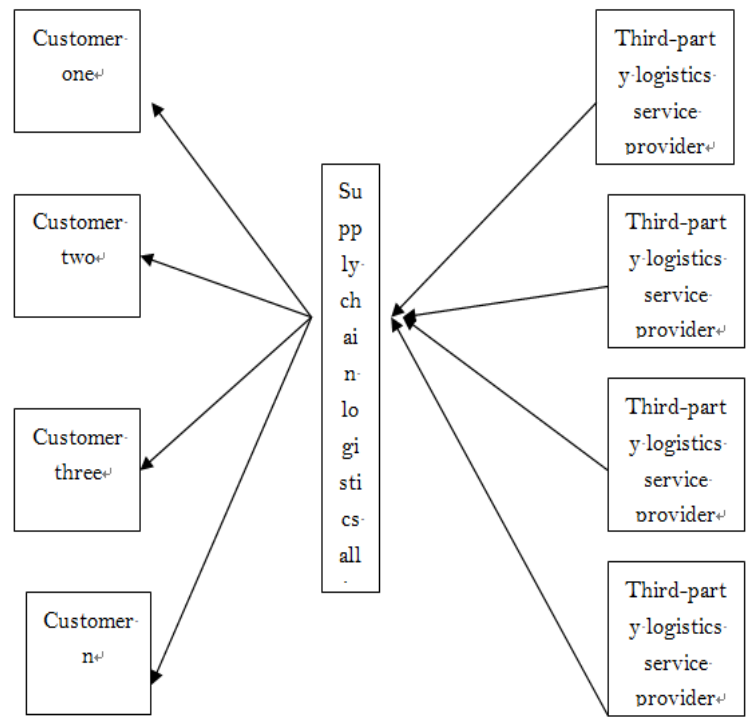

Figure 1.

\section{B. Selection of delivery mode for cold chain logistics}

1) Selection of cold chain logistics mode based on enterprise's self conditions

Based on research of previous people, the paper proposes the selective mode for agricultural products during cold chain logistics delivery with sound suggestions. After a series of analysis, we found that in concrete industry, enterprise's selection of cold chain delivery mode is closely related to its logistics capability and enterprise's strategic development so as to meet enterprise's demand. Based on the analysis above, logistics mode can be selected with specific process shown as Fig .2.

The principle of logistics delivery mode can be determined according to selection and decision-making content of enterprise's cold chain logistics delivery mode. Logistics business which is important for enterprise and can be completed by enterprise self should be self operated; while unimportant logistics without enough advantages should be outsourced; besides, some logistics business without comparative advantages should adopts alliance form if it can't be completed by enterprise self or the company has limited logistics capability, though it is very important for enterprise. The following kinds can be emerged in specific selections.

By comparing enterprise's self cold chain logistics delivery capability with third-party logistics enterprise's cold chain logistics delivery capability, the enterprise can judge if its logistics capability can meet delivery need. If it can meet needs, then analysis should be given on the effect of cold chain logistics enterprise business on enterprise's competitiveness. If cold chain logistics possesses very important position in the enterprise with advantages of self-support cold chain, then self-support logistics can be selected; while if enterprise's logistics capability has no advantage even if its need has been met, then alliance mode with third-party logistics enterprise should be adopted.

By comparing enterprise self cold chain logistics capability with cold chain logistics capability of third-party logistics enterprise, enterprise can judge if its logistics capability can meet the need of cold chain logistics. If the need can be met, then judgment should be made for the effect of cold chain logistics on enterprise's competitiveness. If it has no special strategic advantage, then self-support cold chain can be seen if it has any advantage. If it has, then self-support logistics mode can be

2) Selection of cold chain logistics mode based on different industries

a) Primary products of fruits and vegetables

In recent years, with the development of fruits and vegetables in our country, the annual turnover of fruits and vegetables has reached 300 million tons among the top list in the world. However, the loss rate of fruits and vegetables in our country is as high as $25 \%$ to $30 \%$, and each year economy loss caused by rotten fruits and vegetables reaches 80 billion yuan. The cold chain logistics delivery for fruits and vegetables is a perfect cold chain, which requires the whole process from pick to the last sales to be conducted under certain temperature. The steps of cold chain for fruits and vegetables have formed a complete cold chain from field pick up, refrigerated 
transportation wholesale, fresh supermarket refrigerated sales to final consumers. The specific process see Fig .3.

At present, most agricultural products cold chain logistics should be outsourced to professional third-party cold chain logistics enterprise. By professional service offered by third-party cold chain enterprise, enterprise can improve products' quality, and the rest small part can be delivered to large chain supermarket directly by agriculture-supermarket docking.

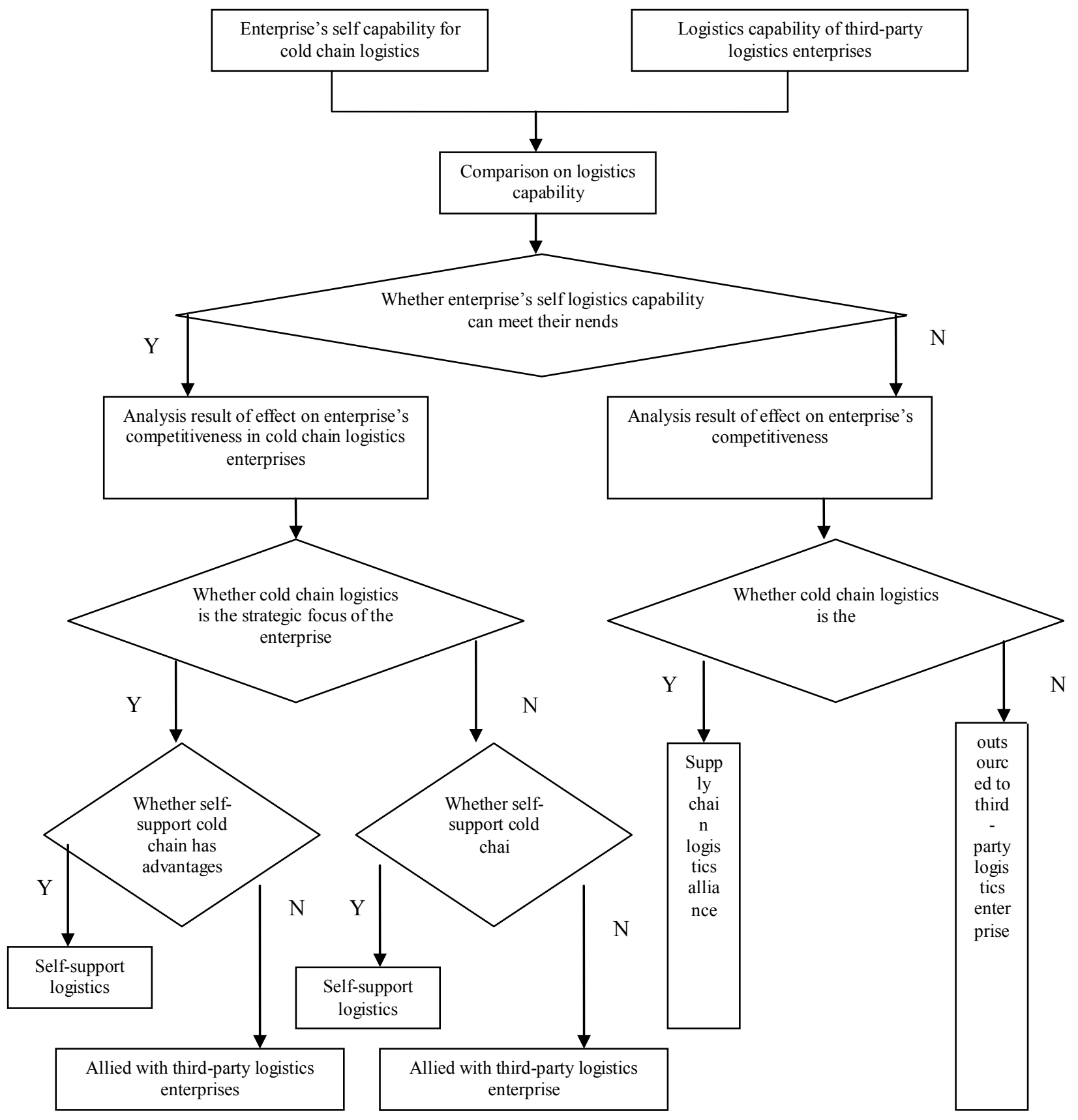

Figure 2. selection and decision-making of enterprise's cold chain logistics delivery mode 


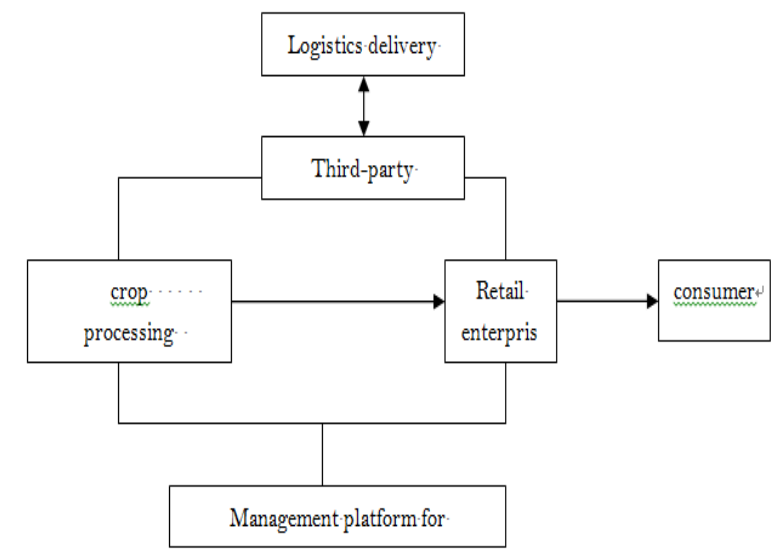

Figure 3. Primary agricultural products cold chain logistics mode of fruits and vegetables oriented by professional third-party cold chain logistics enterprise

\section{b) Diary and meat products}

Although diary products require a higher demand for cold chain technology, now developed countries have already had relatively mature development for diary products cold chain. However, development of diary products cold chain logistics delivery in our country still has many deficiencies, which needs to learn advanced experience from other countries.

Similar to diary products, cooled meat needs to be processed and delivered under low temperature during production and sales, and it can be kept fresh, healthy and convenient only if it is stored under the temperature between 0 to $4{ }^{\circ} \mathrm{C}$. There is strict demand for temperature and time in each section by freshness treatment, commercialization processing as well as grade packing after acceptance until the final refrigeration, pricing, display and sales, within which the overall time should be controlled in two days.

\section{CONCLUSION}

It has been a necessary choice to develop agricultural products cold chain logistics since common delivery mode is suitable for agricultural products cold chain logistics delivery mode in our country. Agricultural products logistics is an important part of socialist market economic construction and development as well as sound measures to guarantee food security. Therefore, it has very significant importance to study agricultural products cold chain logistics delivery mode.
Similarly, at present, with the development of economy globalization, some traditional tariff as well as non-tariff barriers have declined while green barriers are emerging. In recent years, agricultural products in our country have constantly encountered green barriers in global market. Therefore, it has been a necessity for agricultural products to break through overseas green barriers and to participate in international market competition by accelerating cold chain logistics development. At present, agricultural products cold chain logistics has turned to delivery trend of multiple varieties and small bulks, so development of common distribution mode for agricultural products cold chain logistics can not only centralize all cold chain logistics resources and maximize utility rate of logistics materials like personnel, facilities and capital as well as improve agricultural products' delivery quality and service level, but it can also avoid staggered transportation and relieve transportation so as to protect social benefits such as environment. Thus, the implementation joint distribution mode for agricultural products cold chain logistics is of great realistic importance.

\section{REFERENCES}

[1] Guo Jiade. Research on Agricultural Products Cold Chain Logistics Mode And Countermeasures[D]. Wuhan University of Technology, June, 2012.

[2] Du Ranran. Development Status and Existing Problems in Cold Chain Logistics in China[J]. China Securities and Futures. The first issue of 2013

[3] Wen Xiaowei, Da Qingli. Common delivery : Optimal Selection of Cold Chain Logistics Delivery and Transportation Mode in China.[J]Modern Management and Science, the third issue of 2008.

[4] Hong Huanan.Research on Strategies of Common Delivery in Cold Chain Logistics[J].Modern Logistics, the ninth issue of 31 volume.

[5] Jiaojiao Tang, Kai Liu, Qian Chen. Study on cold chain logistics of vehicle routing problem for agricultural products. Guangdong Academy of Agricultural Science, the ninth issue of 2013.

[6] Chenran, Lan Hongjie. Exploration on Common Delivery of Developing Cold Chain Logistics[J].Logistics Engineering and Management, the 31 st volume of 2009.

[7] Liu Zhiyong, Wangkan. Research on Application of Common Delivery in Cold Chain Logistics[J].The tenth issue of 2007.

[8] Liuling.Optimal Path Mode and Control Algorithm of Cold Chain Logistics Delivery[D].Yantai University. June 2012.

[9] ZHAO Gang, ZHANG Yongfeng.On the Cold Chain Logistics Distribution Routing Optimization[J]Proceedings of the 30th Chinese Control Conference, July 22-24. 2011. Yantai. China.

[10] Wang Ying, Chen Xi. Research on vehicle routing problem of cold chain logistics. [J] International Conference on Multimedia Information Networking and Security.2010. 